\title{
Consort Relations of Elements of Arid Agrocenoses as Mechanism for Managing Their Stability and Productivity in Lower Volga Region
}

\author{
Elena Ivantsova \\ Head of the Department of Ecology and Nature \\ Management at Institute of Natural Sciences \\ Volgograd State University \\ Volgograd, Russia \\ Ivantsova@volsu.ru
}

\author{
Nikolay Onistratenko \\ Institute of Natural Sciences \\ Volgograd State University \\ Volgograd, Russia \\ onistratenko@volsu.ru
}

\author{
Anna Kholodenko \\ Institute of Natural Sciences \\ Volgograd State University \\ Volgograd, Russia \\ kholodenko@volsu.ru
}

\begin{abstract}
The need to ensure sustainable development of the agricultural complex in the face of increasing aridity, as well as the need to reduce product contamination with xenobiotics, makes agricultural producers turn to the achievements of environmental science and practically use the general patterns of the structure and functioning of ecosystems. The goal of the authors' research was to clear the ways of influencing agrocenosis through the use of natural consortium relations between different species. The article describes the methods of research and the results, the significance of which for agroecosystems of the Lower Volga region is high due to their wide applicability and the absence of earlier systematized information on this topic. Readers are invited to the typical consortia "cultivated plant-phytophagous", "weed plantphytopathogenic microbiocomplex", "phytophagousentomophage", "cultural plant-entomophage", combination and alternation of which allows us to build manageable trophic chains that naturally reduce the influence of pests and weeds plants onto the cultivated crop.
\end{abstract}

Keywords - plant-animal consortia; consort communications; ecological ways of control; entomocomplex; phytopathogens.

\section{INTRODUCTION}

The urgent problem of rational nature management in the Volgograd region is the sustainability and productivity of agroecosystems in conditions of the increasing aridization of the South of Russia. The transition to ecologization as a paradigm of the agricultural territory development presupposes an adapted approach to the regulation of varying degrees of anthropogenic change of ecosystems. The effectiveness of agrocenoses regulation is impossible without a differentiated effect on biocenotic connections in terrestrial ecosystems.

Russian and foreign researchers [1-4] considered dependence of the material and energy dynamics of biocenosis on the influence of soil and climatic conditions, as well as peculiarities of the aridity influence on the state of natural and artificial ecosystems. However, there are not enough relevant results of detailed studies on this subject, taking into account the natural and climatic characteristics of the Lower Volga region.

The ecological system approach to managing agrocenoses in order to achieve sustainable high productivity of communities, which ensures economic efficiency of production, is the logical development of biologization. The effectiveness of this intervention in the structure and functioning of agrobiocenosis is determined by the consideration of natural ecological mechanisms, which confirms the relevance of the biotechnologies application in agriculture. Biotechnologies can ensure the direct development of biocenoses by the biotic component modulating (plant consortia, entomocomplexes, microbiota) and influencing abiogenic factors (acoustic and optical effects, chemical modifiers), based on advanced scientific achievements. General ecological patterns shift from the category of conditions for the functioning of agricultural production to one of the innovative scientifically based tools [5-6].

The aim of the research was to identify sustainable ecologically significant interrelationships between the defining elements of the ecosystem for the subsequent development of the rationale for subsequent selective intervention in the 
ecosystem with the help of abiotic (physical, chemical) and biotic influences to obtain participants of a certain number and with a certain phenotype under field testing conditions. The results of the research in the introduction of agricultural production suggest scaling and environmental and economic justification for the introduction of environmental biotechnologies on the level of individual farms or territories on the basis of providing detailed information on the mechanisms of interaction at the molecular (biochemical) level with respect to the main participants in arid agrocenoses of the Volgograd Region.

The subject of our research has become specific links between the main elements of the ecosystem, determining the characteristics of its material balance and energy dynamics.

The object of the study was selected characteristic agrocenoses, operating in similar relief and climatic conditions and experiencing comparable in strength, quality and direction impact of human economic activity. As the dominant plant species barley performed (Hordeum vulgareL.). In this article we consider a typical barley field located in the Svetloyarsky region and characterized by a leveling of the relief, light chestnut soils, a high degree of insolation and wind load. The considered region is located on Ergeninskaya elevation and has a relatively low degree of subdivision of the relief. It is characterized by a high degree of aridity, an active manifestation of wind erosion.

The soil cover is represented by light-chestnut, sometimes washed away soils in combination with solonetzes of heavy loam granulometric composition. This type of soil, like chestnut, is characterized by a low thickness of the humus horizon $(25-30 \mathrm{~cm})$, low humus content $(1-2 \%)$, increased salinity and high carbonate content. The cumulative score of bonitet is 50.6-53.7 [8].

High seasonal temperatures, low watercut inherent in the region (cultivation was carried out in a rainfed way) caused a characteristic regional landscape-climatic type of territory - a southern dry-steppe with an evolving aridization trend. The comparatively high weediness of the field, observed even by the naked eye, could be the result of violations during the implementation of agrotechnical measures.

\section{MATERIALS AND METHODS}

The investigated phytocenoses were studied within the limits of geobotanical sites laid on the terrain according to the generally accepted methods $[8,9]$. The area of the geobotanical site was $100 \mathrm{~m} 2(10 \times 10 \mathrm{~m}$ square). The definition of plant species was made from the observed vegetative or dried samples, which have readable diagnostic features. Literature sources and databases were used for the determination $[11,12]$. The abundance was estimated on the Drude scale with A.A. Uranov's additions [12], P.D. Yaroshenko [13] and A.P. Shennikov's digital scale [14]. The density of plants per $1 \mathrm{~m} 2$ was determined using the Ramensky grid. Projective coverage was also determined by the Ramensky grid.

Ecological faunistic studies were carried out using conventional methods [15-24]. Monitoring of the composition and density of entomocomplexes was carried out throughout the growing season. Insects were recorded using improved methods. An openly living insects' census was carried out by counting individuals on stationary sites (20 sites measuring $0.25 \mathrm{~m}^{2}$ ). Soil entomofauna was taken into account by the soil excavations method (20 soil samples of $0.25 \mathrm{~m} 2$ at a depth of $30 \mathrm{~cm}$ ), followed by the transfer of density to $1 \mathrm{~m} 2$. Collection and recording of herpetobionts were carried out using the Barber traps with formalin. Collection and recording of the herbage inhabitants (chortobionts) were carried out by mowing with an entomological net - 25 strokes in a fourfold repetition.

When assessing the infection of parasites of grass flies on the field, samples of stems were selected, which were carefully examined and opened. The detected larvae and puparia were removed from the stems. The larvae were opened on a slide in a drop of water and the presence or absence of parasite larvae was established. Puparia were placed in test tubes or Petri dishes to hatching parasites. To register parasitic parasite infestation, all phases of development, healthy, mummified, were counted during the recording of the latter, and then the percentage of parasites was calculated $[23,24]$. Collection, excretion and storage of entomophages were carried out according to V.A. Trjapitsyna, V.A. Shapiro, V.A. Schepetilnikova [25]. The collected entomological material was determined at the Department of Ecology and Nature Management of VolSU for control samples and determinants of V.S. Velikan et al. [26], G.E. Osmolovsky [27], V.A. Megalov [17] and others.

Ecological and floristic studies were conducted using conventional methods and special guidelines on the causative agents of diseases of the corresponding cultures [28-35].

\section{RESULTS AND DISCUSSION}

Agrocenosis, located near the southern tip of Volgograd in the Svetloyarsky district, is typical for its biotopic characteristics for the Southern dry-steppe region. The description of the geobotanical site is presented in Tables 1 and 2. The size of the trial area for the geobotanical description was $10 \times 10 \mathrm{~m}$. The name assigned to the association being described is cereal (barley field). The geographical address is Volgograd region, Svetloyarsky district, the field at the federal highway. The general character of the relief is flat with a developed ravine-beam net opening into the Volga riverbed, the aligned microrelief. The average loam was determined as the surface rock, the soil was defined as light kastanozem with a thickness of the upper humified layer of $5 \mathrm{~cm}$ and the root layer $-40 \mathrm{~cm}$. In the survey area, the humidification conditions characterized as rainfall correspond to the climate, and the depth of the groundwater is 6-7 $\mathrm{m}$. The technogenic environment of the survey area from the north is a highway, from the south - cultivated fields, from the west - cultivated fields, from the east - cultivated fields and field road. The impact of humans and animals includes the cultivation of crops and the impact of transport. The dead litter (composition, thickness, degree of coverage, distribution pattern) represents the dead herbaceous vegetation of the past and this year, the litter is abundant, covers the soil; its thickness is $2 \mathrm{~cm}$. 
For the grass and shrub cover, the degree of the projective coverage was $40 \%$, the seediness (true coverage) - $20 \%$; the aspect is characterized as straw yellow with the interspersing of green.

TABLE I. SPECIES STRUCTURE AND IMPORTANT BIOLOGICAL CHARACTERISTICS OF PHYTOCENOSIS

\begin{tabular}{|c|c|c|c|c|c|c|}
\hline No. & Species of plant & $\begin{array}{c}\text { Height, } \\
\text { cm }\end{array}$ & Abundance & $\begin{array}{c}\text { Projective } \\
\text { coverage, } \%\end{array}$ & Phoenophase & Type of accommodation \\
\hline 1 & $\begin{array}{c}\text { Barley (Hordeum } \\
\text { vulgare) }\end{array}$ & 60 & +++ & 30 & $\begin{array}{l}\text { fruiting / } \\
\text { dying out }\end{array}$ & everywhere, evenly \\
\hline 2 & $\begin{array}{c}\text { Common chicory } \\
\text { (Cichorium intybus) }\end{array}$ & 60 & ++ & 40 & flowering & everywhere, in groups \\
\hline 3 & $\begin{array}{c}\text { Cornbind bindweed } \\
\text { (Convolvulus } \\
\text { arvensis) }\end{array}$ & 60 & ++ & 70 & flowering & everywhere, evenly \\
\hline 4 & \begin{tabular}{|l|} 
Turgenia broadleaf. \\
(Turgenia latifolia)
\end{tabular} & 40 & + & 60 & fruiting & everywhere, in groups \\
\hline 5 & $\begin{array}{c}\text { Yellow sweet clover } \\
\text { (Melilotus } \\
\text { officinalis) }\end{array}$ & 110 & + & 40 & end flowering & everywhere \\
\hline 6 & $\begin{array}{l}\text { Field larkspur } \\
\text { (Delphinium } \\
\text { consolida) }\end{array}$ & 50 & + & 30 & flowering & everywhere \\
\hline
\end{tabular}

The moss-lichen cover is absent. Extra-stage vegetation (lianas, epiphytes, species composition, abundance, attachment height) is also absent.

General remarks for the entire phytocenosis: agrocenosis is affected by adverse natural (climatic, hydrological) and anthropogenic (transport, industrial emissions, spontaneous rest) factors. Crops are strongly clogged.

The vertical structure of agrocenosis is leveled. One tier is formed by the main crop - Common Barley.

When characterizing zoocenoses, emphasis is placed on the description of the entomocomplex as the main participant of the biocenosis when forming connections with plants and soil in relation to the subject matter of the project.

As a result of entomomonitoring research of the spring barley agrocenoses, we recorded 40 specialized species of herbivores as polyphagous. The most common and harmful species are cereal flies (Oscinella pusilla Mg., O. frit L. , Mayetiola destructor Say). During wet and warm springs, a significant harm can be caused by cereal aphids (Sitobion avenae F., Brachycolus noxius Mordv., Rhopalosiphum padi L., Aphis evonymi $F$.). In some years, among the polyphagous pests, there is the winter moth (Scotia segetum Schiff), the wireworm (Agriotes spp.). In addition to highly specialized pests, representatives of the entomofauna of natural cenoses and typical phytophages of weeds were noted .

Entomophages are among the permanent elements of agrobiocenosis, the ecological features and structure of which determine the exceptional diversity in the relationship between organisms and biological systems, the host parasite, the predator-prey. In this case, each species inhabits a certain environmental compartments, has its own development cycle and, accordingly, the level of specialization. In this regard, the activation of predators and parasites presupposes, in the first place, the availability of data on their species diversity, biology and relationships with harmful insects. The creation of optimal conditions for the activation of beneficial organisms and also the unfavorable environment for pests occurs by introducing into the agrolandscape. The reserves of natural entomophage populations and the placement around them of buffer zones, where useful organisms of natural habitats adapt to new conditions, promote the inclusion of mechanisms of biocenotic regulation of agrosystems that are capable of modifying the long-term tendency of the phytosanitary state towards decreasing the average number of pests and the development of pathogens.

Shallow species of predatory ground beetles can destroy cereal flies. We bred the parasites of larvae Merisus destructor Say., Trichomalus cristatus Foerst, Coelinidea sp., Eupteromalus subaterus Riley., Rhoptromeris sp from the flies puparia. The percentage of infected puparium flies is small. Imago riders are present on crops of cultivated cereals throughout the vegetative period of plants. Ticks (the species is not defined) parasitize on the body of adults of Swedish flies, sometimes 3-4 on one individual. The effectiveness of parasites depends to a large extent on the proximity of the location of grain crops to natural habitats with wild or cultured nectarifers. The following coccinellids have the greatest value in suppressing the number of gramineous aphids: 2-point (Adalia bipunctata L.), 5-point (C. quinquepunctata L.), a 7spotted ladybug (Coccinella semtempunctata L.), 14- point ( $C$. quatuordecimpunctata L.), the variated ladybug (Adonia variegata Gz.), and 14-point propylaea (Propylea quatuordecimpunctata L.). Larvae syrfid-flies (Syrphus andrcuatus Fall., S. ribesii L., S. luniger $\mathrm{Mg}$.) are very important in the destruction of cereal aphids. In the spring period, adult flies can often be seen eating nectar and pollen on the flowers of weeds from the families of Euphorbia, Umbelliferae, Cruciferae, and others; on the fields located near forest belts, the number of syrfids is higher. Cereals thrips are destroyed by carnivorous beetles; coccinelida, chrysopa, staphylines, predatory bugs and spiders [28]. Larvae and adults feed on striped thrips (Aeolothrips fasciatus L.), 
Melanthrips sp. and Ripidothrips sp., which appear during the colonization of crops with wheat thrips. Potential regulators of the number of wheat thrips during the transition to wintering in the soil should be attributed according to E.V. Komarov and Soboleva-Dokuchaeva [29] to beetles Pterostichus puncticollis and $P$. cupreus. The dynamism of the impact on the phytophagous predatory and parasitic species that act on different stages of plant chaotogenesis creates a prerequisite for the management of pest populations in agroecosystems.

The establishment of regularities in the distribution of insect species in agrocenosis and their interrelationships makes it possible to identify permanent consortia, the use of which can be regarded as one of the mechanisms for the ecologization of agricultural production. The use of not just individual species, but sustainable consortia, will ensure longterm autonomous work of the launched mechanism of ecological control of agricultural pests, unify agroecotechnology of the arid region. The stable dependences of the distribution of plant species and insect groups are shown in Table 2.

TABLE II. CONSORT COMMUNICATIONS "PLANTS-INSECTS" (SECTION III, SVETLOYARSKY DISTRICT, FIELD №2, ASSOCIATION NAME: CEREAL-FORB)

\begin{tabular}{|c|c|c|c|c|}
\hline \multirow{2}{*}{ No. } & \multirow{2}{*}{ Species } & \multicolumn{3}{|c|}{ Ecological groups of insects } \\
\hline & & phytophagous & entomophages & pollinators \\
\hline 1 & $\begin{array}{l}\text { Couch grass } \\
\text { (Elytrigia } \\
\text { repens } \\
\text { (L.) Nevski.) }\end{array}$ & $\begin{array}{c}\text { Onconotus } \\
\text { laxmanni Pall } \\
\end{array}$ & & \\
\hline 2 & $\begin{array}{c}\text { Sun spurge } \\
\text { (Euphorbia } \\
\text { helioscopia } \\
\text { L.) }\end{array}$ & & & $\begin{array}{l}\text { Anthophoraers } \\
\text { chowi Fedt . }\end{array}$ \\
\hline 3 & $\begin{array}{l}\text { Field larkspur } \\
\text { (Delphinium } \\
\text { consolida) }\end{array}$ & & & $\begin{array}{c}\text { Bombus } \\
\text { serrisguama L. }\end{array}$ \\
\hline 5 & $\begin{array}{l}\text { Tatar orach } \\
\text { (Atriplex } \\
\text { tatarica L.) }\end{array}$ & $\begin{array}{l}\text { Phyllotreta } \\
\text { spp. }\end{array}$ & $\begin{array}{c}\text { Adalia } \\
\text { bipunctata L. }\end{array}$ & $\begin{array}{c}\text { Apis mellifera } \\
\text { L. }\end{array}$ \\
\hline 6 & $\begin{array}{l}\text { Tatar lettuce } \\
\text { (Lactuca } \\
\text { tatarica (L.) } \\
\text { C.A.Mey.) }\end{array}$ & $\begin{array}{c}\text { Pieris } \\
\text { brassicae L. }\end{array}$ & $\begin{array}{c}\text { Elodia tragica } \\
\text { Mg. } \\
\text { Collyria with } \\
\text { oxator Vill . }\end{array}$ & $\begin{array}{c}\text { Apis mellifera } \\
\text { L. } \\
\text { Agrius } \\
\text { convolvuli L. } \\
\text { Bombus } \\
\text { terrestris L. }\end{array}$ \\
\hline 7 & $\begin{array}{c}\text { Cornbind } \\
\text { bindweed } \\
\text { (Convolvulus } \\
\text { arvensis L.) }\end{array}$ & $\begin{array}{l}\text { Lygus } \\
\text { pubescens } \\
\text { Reut }\end{array}$ & & $\begin{array}{c}\text { Apis mellifera } \\
\text { L. } \\
\text { Bombus spp. } \\
\text { Dasypoda } \\
\text { plumipes } \\
\text { Panz. }\end{array}$ \\
\hline
\end{tabular}

There is no doubt that the study of entomo-communities is of great interest for the knowledge of biogeocenoses of the arid zone. The composition of the entomofauna of agrobiocenoses, as is known, is not stable. Being formed every year under the influence of various factors, the fauna structure in time and space has undergone and continues to undergo very significant changes, both qualitatively and quantitatively. At the same time, there is a more or less constant number of species that make up the main nucleus of the entomofauna of field crops.
As a result of the studies, the pathogenic complex on spring barley, the ecological role of the pathogen, and the occurrence were revealed (Table 3).

TABLE III. SPECIES COMPOSITION, ECOLOGICAL ROLE AND INVOLVEMENT OF THE CAUSES OF DISEASES OF THE YARN BARLEY

\begin{tabular}{|c|c|c|c|}
\hline Disease & Causative agent & $\begin{array}{l}\text { Ecological } \\
\text { role }\end{array}$ & $\begin{array}{c}\text { Occurrence, } \\
\%\end{array}$ \\
\hline Stem rust & $\begin{array}{l}\text { Puccinia graminis } \\
\text { Pers. }\end{array}$ & $\mathrm{m}$. & $5.3-19.0$ \\
\hline Powdery mildew & $\begin{array}{l}\text { Blumeria graminis } \\
\text { (DC) Speer. }\end{array}$ & s.p. & $31.1-56.8$ \\
\hline Root rot & $\begin{array}{c}\text { Species of fungi } \\
\text { Fusarium, } \\
\text { Helminthosporium } \\
\end{array}$ & $\mathrm{m}$. & $38.8-65.2$ \\
\hline Septoria & $\begin{array}{l}\text { Septoria tritici Rob. et } \\
\text { Desm. }\end{array}$ & s.e. & $10.5-20.3$ \\
\hline Ascochitis & $\begin{array}{c}\text { Ascochyta } \\
\text { graminicola Sacc. }\end{array}$ & s.e. & $10.6-13.2$ \\
\hline $\begin{array}{c}\text { Mesh } \\
\text { helminthosporium }\end{array}$ & $\begin{array}{l}\text { Helminthosporium } \\
\text { teres Sacc. }\end{array}$ & s.e. & $10.1-19.3$ \\
\hline Striped spotting & $\begin{array}{l}\text { Helminthosporium } \\
\text { gramineum Rabh. }\end{array}$ & s.e. & $11.7-29.1$ \\
\hline Black seed germ & $\begin{array}{l}\text { Alternaria tenuis } \\
\text { Nees., } \\
\text { Helminthosporium } \\
\text { sativum Pam. } \\
\end{array}$ & $\mathrm{m}$. & $12.8-15.1$ \\
\hline Seed Breeding & $\begin{array}{l}\text { fungi Fusarium, } \\
\text { Aspergillus glaucus } \\
\text { Fr., Penicillium } \\
\text { graucum Fr. }\end{array}$ & s.e. & $11.1-20.5$ \\
\hline Bacterial leaf spot & $\begin{array}{c}\text { Xanthomonas } \\
\text { campestris var. } \\
\text { Hordei Dows., } \\
\text { Baccilus cerealinus } \\
\text { Gentner. }\end{array}$ & s.e. & units \\
\hline
\end{tabular}

Analysis of species composition of pathogens indicates that micromicetes perform the role of the main sheet of plant pathogens and pathogens of root rot.

Species composition of pathogenic microflora of natural phytocenoses is more diverse in comparison with agrobiocenoses, but it is distributed separately on separate plants with greater amplitude in the development of the disease, which is associated with a diverse species composition of feeding plants and the specificity of their growth. Data on the pathogenic complex of weed and wild plants for the conditions of the Volgograd region are practically absent.

As a result of the conducted studies it was established that the species diversity of micromycetes is represented by real fungi from the classes of ascomycetes, basidiomycetes and deuteromycetes (table 4). The total list of identified fungi was 23 species. According to the number of species, the genera are Erysiphe, Puccinia and Septoria. The rest of the genera are represented by 1-2 species.

Below is a systematic list of identified species of fungi. This list includes phytopathogens not only on segetal weeds, but also on a number of wild herbaceous plant habitats with anthropogenic influence. Their reduction is of interest, since ruderal plots serve as reserves of weeds, which, when 
conditions change, can be introduced into agrocenoses, as well as phytopathogens - potential candidates for biocontrol.

TABLE IV. PATHOGENIC COMPLEX OF WEED AND WILD VEGETATION IN RESEARCH PLOTS

\begin{tabular}{|c|c|}
\hline Name of host plant & Pathogen of the disease \\
\hline \multicolumn{2}{|c|}{ Eumycota, Ascomycetes, Erysiphales } \\
\hline Elytrigia repens (L.) Nevski & Blumeria graminisSpeer. \\
\hline Bromus inermis L. & Erysiphe festucaeJacz. \\
\hline Convolvulus arvensisL. & Erysiphe graminis f. covolvuli P. \\
\hline Artemisia sp. & Erysiphe graminis f. agropyre Yacz. \\
\hline $\begin{array}{l}\text { Polygonum convolvulus L. } \\
\text { Cichorium intybus L. }\end{array}$ & $\begin{array}{l}\text { Erysiphe communis Grev. } \\
\text { Erysiphe cichoracearum DC. }\end{array}$ \\
\hline Melilotus officinalis (L.) Pall. & $\begin{array}{l}\text { Erysiphe communis Grev. } \\
\text { Leveillula taurica Arnaud. }\end{array}$ \\
\hline \multicolumn{2}{|c|}{ Basidiomycetes, Uredinales } \\
\hline Polygonum aviculare L. & Puccinia polygoni Alb. et Schw. \\
\hline Artemisia sp. & Puccinia artemisiella Syd. \\
\hline \multicolumn{2}{|c|}{ Deuteromycetes, Hyphomycetales } \\
\hline \multirow{2}{*}{ Ambrosia artemisifoliaL } & Botrytis sp. \\
\hline & Alternaria sp. \\
\hline \multirow{2}{*}{ Bromus arvensis L. } & Fuzarium sp. \\
\hline & Helminthosporium sativum Pam \\
\hline Artemisia $\mathrm{sp.}$ & Cladosporium fuscum Zink. \\
\hline $\begin{array}{l}\text { Convolvulus arvensis L. } \\
\text { Cichorium intybus L. }\end{array}$ & $\begin{array}{c}\text { Cladosporium herbarum (Pers.) Link. } \\
\text { Botrytis cinerea (P.) Fr.J }\end{array}$ \\
\hline \multicolumn{2}{|c|}{ Sphaeropsidales } \\
\hline Bromus arvensis L. & Septoria draminum Dasm. \\
\hline \multirow[t]{2}{*}{ Convolvulus arvensis L. } & $\begin{array}{l}\text { Septoria convolvuli Desmaz. } \\
\text { S. longispora Bondartsev. }\end{array}$ \\
\hline & Phyllosticta calystegiae Sacc. \\
\hline $\begin{array}{l}\text { Amaranthus spp. } \\
\text { Cichorium intybus L. }\end{array}$ & $\begin{array}{l}\text { Phyllosticta atriplicum Desm. } \\
\text { Seotoria intybi Pass. }\end{array}$ \\
\hline
\end{tabular}

The wide prevalence of septoriosis and powdery mildew on field bindweed and high ecological plasticity of these pathogens cause further study of them as biocontrol candidates.

Thus, the reserve plants of pathogens of fungal diseases among meadow and weed vegetation have been identified, from which the infectious origin can be transferred to cultivated plants, as well as micromycetes, among which there may be potential candidates for biocontrol.

\section{CONCLUSION}

Among the studied representatives of the entomofauna, not only phytophages but also entomophages have been detected, which make it possible to regulate the number of pests of cereal crops. Weeds that occur in barley agrocenosis are often consorts of entomophages that provide environmentally determined pest control. The regulation of the number of unwanted plants in agrocenosis is also possible due to the presence of specialized phytopathogenic mycobacteria and bacteriocomplexes found on them. It is also possible to introduce these microorganisms into the community to reduce the contamination of crops and as a terminal phase of environmental pesticide stripping.

Identified consortium links of ecosystem elements open up the possibility of purposeful high-precision impact on organisms unwanted in agrocenosis. And the impact will not be provided by introducing xenobiotics or physical destruction of biota, but by strengthening and redirecting the work of natural ecological patterns and mechanisms. Gentle influence on agrocenosis and adjacent communities will ensure longterm sustainable and productive coexistence of natural, quasinatural and anthropogenically altered communities, which fully meets the requirements of production ecologization in the paradigm of sustainable development.

\section{Acknowledgment}

The study was carried out with the financial support of the State task of the Ministry of Education and Science of the Russian Federation within the framework of the project of the Russian Humanitarian Scientific Foundation (RGNF) No. 40.7534.2017/8.9 "Development of ecologically-oriented biotechnologies for the optimization of arid agrobiocenoses in the South of Russia based on the achievements of physicchemical biology and bioinformatics"

\section{References}

[1] T.A. Trifonova, L.A. Shirkin, N.V. Mishchenko, "Modeling of the stationary states of the phytocenosis-soil system", Pedology, vol. 8, 2012, pp. 889

[2] K.B. Mushaeva, "Kalmykiya with GIS-technologies", Science journal of Volgograd state university. Natural sciences. Series 11., vol. 1, 2015, pp. 103-110.

[3] M. He, F.A. Dijkstra, K. Zhang, X. Li, H. Tan, Y. Gao, G. Li, "Leaf nitrogen and phosphorus of temperate desert plants in response to climate and soil nutrient availability", Sci. Rep., vol. 4, 2014, p. 6932.

[4] W.S. El-Sayed, A. Akhkha, M.Y. El-Naggar, M. Elbadry, "In vitro antagonistic activity, plant growth promoting traits and phylogenetic affiliation of rhizobacteria associated with wild plants grown in arid soil”, Front. Microbiol., vol. 5, 2014, p. 651.

[5] A.F. Zubkov, "Agrobiotecnologia modernization of plant protection", In Plant Protection Bulletin, Supplements, vol. 12. St. Petersburg: VIZR, 2014, p. 116.

[6] L.V. Dudchenko, "An effective biological method for suppressing weeds in protected forest plantations", Achievement of science and technology, vol 7, 2012, pp. 37-38.

[7] A.N. Sazhin, K.N. Kulik, Yu.I. Vasilyev, Weather and climate of the Volgograd region. Volgograd: VNIALMI, 2010, p. 306.

[8] L.N. Hudson, T. Newbold, S. Contu, S.L.L. Hill., I. Lysenko, A. De Palma, et al, "The database of the PREDICTS (Projecting Responses Diversity of Ecological In Changing Terrestrial Systems) project”, Ecol. Evol., vol. 7 (1), 2017, pp. 145-188.

[9] V.V. Alekhin, D.P .Syreishchikov, Methods of field Botanical research, Vologda: Severnyi pechatnik, 1926, p. 141.

[10] V.S. Ipatov, D.M. Mirin, Description of phytocenosis: guidelines. St. Peterburg, 2008, p. 70.

[11] P.F. Maevskii, Flora of the average of the European part of Russia. Moscow: Tovarishchestvo nauchnykh izdanii KMK, 2014, p. 635.

[12] I.N. Penkova, O.V. Permyakova, Pasture ecosystems of the Lower Volga region. Volgograd: FGBOU VPO Volgogradskii GAU, 2014, p. 176.

[13] A.A. Uranov, V.V. Alekhin, et al, "About the Drude method", Byul.MOIP, vol. XLIV, iss. 1-2, pp. 18-31.

[14] A.P. Shennikov, Introduction to geobotany. Leningrad: Izd-vo Leningradskogo universiteta im. AA Zhdanova, 1964, p. 447.

[15] P.D. Yaroshenko, Geobotany. Moscow: Prosveshchenie, 1969, p. 200. 
[16] B.V. Dobrovolskii, Insect phenology. Moscow: Vysshaya shkola, 1969, p. 232.

[17] V.G. Dolin "The identification and quantification of crop pests", Pests of agricultural crops and forest plantations, Kiev, 1989, vol. 3, pp. 341-344.

[18] I.V. Kozhanchikov, Research methods of insect ecology. Moscow: Vysshaya shkola, 1961, p. 286.

[19] N.I. Kulikov, "Mowing with a net-method of accounting for insects", Plant protection and quarantine, vol.6, 1999, pp. 32-33.

[20] V.A. Megalov, The identification of pests of field crops. Moscow: Kolos, 1968, p. 176

[21] A.F. Zubkov, Guidelines for the collection of field biocenological information. Leningrad: VIZR, 1978, p. 18.

[22] V. I. Tansky , M. M. Levitin , T. I. Ishkova, V. I. Kondratenko, "The accounting methods of harmful organisms: recommendations of the VIZR", Plant protection and quarantine, vol. 2, 2002, p. 6.

[23] "The accounting methods of harmful organisms: recommendations of the VIZR", Plant protection and quarantine, vol. 6, 2003, p. 43.

[24] Yu.B. Shurovenkov, A.F. Chenkin, Recommendations on accounting and detection of pests and diseases of agricultural plants, Voronej: VNIIZR, 1984, p. 272.

[25] V.A. Tryapitsyn, V.A. Shapiro, V.A. Shchepetil'nikova, Parasites and predators of pests of agricultural crops. Leningrad: Kolos, 1982, p. 256.
[26] V.S. Velikan, V.B. Golub, E.L. Guryeva, et al, Keys to harmful and useful insects and mites on grain plants in the USSR. Leningrad: Kolos, 1980, p. 335 .

[27] G.E. Osmolovskii, Identification of agricultural pests and systematization of the terms of their control. Moscow: Rosselkhozizdat, 1964, p. 204.

[28] E. Goiman, Infectious diseases of plants. Moscow, 1954, p. 608.

[29] A.F. Chenkin, V.A. Zakharenko, G.S. Belozerova, et al, Phytosanitary diagnostics. Moscow: Kolos, 1994, p. 320.

[30] V.G. Kaplin, G.V. Leontieva, A.M. Makeeva et al, Phytosanitary control and protection of cereals from diseases and pests, Samara, 2000, p. 110.

[31] Index of pathogens of agricultural plants, " M.K. Khokhryakov Ed. VIZR, Leningrad, 1971, p. 99.

[32] V.A. Chulkina, Epiphytotiology of infectious diseases of plants, Novosibirsk, 1988, p. 56.

[33] M.K. Khokhryakov, T.L. Dobrozrakova, K.M. Stepanov, M.F. Letova, Manual of plant diseases. Moscow: Lan, 2003, p. 592.

[34] M.K. Khokhryakov, V.I. Potlaichuk, A.Ya. Semenov, M.A. Elbakyan, Manual of diseases of agricultural crops. Moscow: Kolos, 1984, p. 304.

[35] S.N. Shamrai, V.I. Glushchenko, Foundations of the field in the study of plant pathology and photoimmunology. Kharkov: KhNU, 2006, p. 64. 